\title{
Knowledge complexity and firm performance: evidence from the European SMES
}

Article

Accepted Version

Audretsch, D. B. and Belitski, M. (2021) Knowledge complexity and firm performance: evidence from the European SMEs. Journal of Knowledge Management, 25 (4). pp. 693-713. ISSN 1367-3270 doi: https://doi.org/10.1108/JKM-03-2020-0178 Available at https://centaur.reading.ac.uk/96384/

It is advisable to refer to the publisher's version if you intend to cite from the work. See Guidance on citing.

To link to this article DOI: http://dx.doi.org/10.1108/JKM-03-2020-0178

Publisher: Emerald

All outputs in CentAUR are protected by Intellectual Property Rights law, including copyright law. Copyright and IPR is retained by the creators or other copyright holders. Terms and conditions for use of this material are defined in the End User Agreement.

$\underline{\text { www.reading.ac.uk/centaur }}$

\section{CentAUR}


Central Archive at the University of Reading

Reading's research outputs online 


\title{
Knowledge Complexity and Firm Performance: Evidence from the European SMEs
}

\author{
David B. Audretsch \\ Indiana University Bloomington, United States \\ daudrets@indiana.edu \\ Maksim Belitski ${ }^{1}$ \\ Henley Business School, University of Reading. United Kingdom \\ m.belitski@reading.ac.uk
}

\begin{abstract}
Despite valuable prior research on knowledge complexity, the inter-connectedness of various acumens of knowledge complexity and its relationship to firm performance requires further exploration. This study theoretically debates and empirically tests the relationship between three acumens of knowledge complexity and firm performance, adding a firm resilience dimension. We use primary data collected from 102 European small and medium-sized firms (SMEs) in Belgium, Bulgaria, Denmark, Spain, and the United Kingdom (UK) observed during 2012-2014 and 2018-2020. Results provide new insights on firm management and policy development for scholars, managers, and policymakers.

Keywords: inter-organizational collaboration, resilience, firm performance, knowledge complexity, SMEs
\end{abstract}

\section{Introduction}

The complexity of the business environment has significantly increased over time. In the face of the grand challenges of globalization, technological innovation, climate, and social change, managers are searching for more efficient and agile approaches to knowledge creation and management (Merritt, 1974; Chakravarthy, 1997; Weber and Tarba, 2014; Soto-Acosta and Cegarra-Navarro, 2016; Soto-Acosta et al. 2018; Shams et al. 2019). Recently, the corporate world has incorporated the acronym VUCA (volatility, uncertainty, complexity, and ambiguity) that expresses the speed of change, the unpredictability of events, the multiplicity of forces, and

\footnotetext{
${ }^{1}$ Correspondent author
} 
various ways of seeing the reality that respectively best describe the environment (Bennis and Nanus, 1985). The VUCA-environment requires a different approach to knowledge creation, absorption, and commercialization by firms, with SMEs most affected due to lack of trained skills, budget, and other resources (van de Vrande et al. 2009; Vahter et al. 2014; Oliva and Kotabe, 2019).

As internal resources are oftentimes limited, SMEs to a greater extent than larger firms depend upon external knowledge collaborations and spillovers (Jaffe, 1989; Audretsch and Feldman, 1996; Durst and Edvardsson, 2012). Their economic burden makes them search for commercially exploitable new knowledge combinations (Hargadon and Sutton, 1997) as SMEs face unique knowledge management challenges that are distinct from those of incumbent larger firms. Reviewing the literature related to SMEs' knowledge management suggests that scholars tend to apply approaches originally developed for larger firms rather than SMEs. This procedure involves the risks that the decision-making in smaller-firms and their productivity frontier in the industry is different from the large firms (Durst and Edvardsson, 2012). While achieving greater firm performance is the ultimate objective of many SMEs (Brunswicker and Vanhaverbeke 2015; Khalil and Belitski, 2020), the returns to knowledge investment vary significantly between SMEs (Usman et al. 2018).

This heterogeneity is often overlooked when researching knowledge management and its effect on firm performance in SMEs (Curran and Blackburn, 2001). SMEs are difficult to contrast with each other due to the level of technology and skills development, making the notion of one single knowledge management approach impossible in SMEs (Durst and Edvardsson, 2012). 
To leverage the external shocks, SMEs employ a variety of knowledge sources (van Beers and Zand, 2014; Roper et al. 2017; Oliva, 2014; Soto-Acosta and Cegarra-Navarro, 2016; Oliva et al., 2018; Audretsch and Belitski, 2019) and exploiting the synergies between the strategic, managerial and organizational components (acumens) of knowledge complexity (von Hippel, 2005; Brunswicker and Vanhaverbeke, 2015).

This study objective is to theoretically discuss and empirically investigate the extent to which the interplay between the domains of knowledge complexity (managerial, strategic, and operational) facilitates firm performance and the role of organizational resilience in this relationship.

To identify and understand the interplay between each acumen of knowledge complexity and we draw on the literature which explains how inter-and intra-organizational knowledge (Leidner, Lo, and Preston, 2011; West and Bogers, 2017) and organizational resilience (Akgün and Keskin, 2014) contribute to the development of absorptive capacity and eventually firm performance.

We use data available from two rounds of the e-leadership online survey of 102 SMEs observed in 2012-2014 and 2018-2020 in five European countries (the UK, Denmark, Belgium, Spain, and Bulgaria) to test our research hypothesis. There are several important findings in this paper. First, compared to other acumens of knowledge complexity, managerial and operational acumens contribute most the most to a firm's performance (sales and productivity) (Belitski and Liversage, 2019). Firm resilience positively moderates managerial skills and negatively moderates inter-organizational collaborations. This finding provides important insights for SMEs embedded in the VUCA environment (Mueller et al. 2013; Kobarg et al. 2019) and particularly 
in developing countries and the early-stage growth when resources are limited (Kothari, Kotabe and Murphy, 2013).

Taking SMEs and their inter-organizational relationships, skills, and resilience in focus, considering that they are transitive organizations whose business model is based on innovation and productivity to outcompete larger counterparts (Teece, Pisano and Shuen, 1997), it is found that resilience and agility in SMEs are important to leverage the effect of knowledge complexity and enhance firm performance (Oliva and Kotabe, 2019).

The remainder of this paper is organized as follows. The next section sets out the hypotheses. Section 3 introduces the data and methodology. Section 4 presents the results, while Section 5 concludes and discusses a range of limitations, policy implications, and future research.

\section{Theoretical framework}

\subsection{Knowledge complexity and firm performance}

Firms rely on external knowledge to complement firm's internal knowledge capabilities (Kotabe, Jian, and Murray, 2014). Inter-organizational collaboration helps firms to increase their economic value-added and boost a firm's growth and productivity (Dyer and Singh, 1998) by integrating, modifying, and creating new combinations of resources with those available in a firm (Barney et al. 2001). These major benefits of inter-organizational collaboration have been

illustrated in the open innovation literature (West et al. 2014; Spender et al., 2017; Cavusgil and Knight, 2015) and in particular on the importance of inter-organizational collaboration between firms at a different level of growth and size (Yoon and Hughes, 2016). Firstly, the ability to access external and diverse knowledge (Kobarg et al. 2019) facilitates the firm's innovation search and performance. Secondly, inter-organizational collaboration helps firms to distribute the 
costs of innovation between their partners (Cheng and Fu, 2013; West and Bogers, 2017).

Thirdly, the increasing complexity, which includes a combination of managerial skills, strategic orientation in a market, and knowledge of operations and information technologies (IT) -demands a greater variety of collaborators and diversification of functional dimensions of knowledge (Soto-Acosta and Cegarra-Navarro, 2016; Martinez-Conesa et al. 2017).

Most SMEs have no explicit policy targeted at knowledge management, and they tend to treat it as an operational acumen (Durst and Edvardsson, 2012) of systems and instruments. SMEs focus on tacit knowledge management, and networks are more likely to be between SMEs than SMEs and larger firms. The SMEs are less advanced than large firms in knowledge construction, having a more operational approach. SMEs are weaker than larger counterparts in adopting various technologies as well as the development and implementation of strategic thinking (Beijerse, 2000; McAdam and Reid, 2001; Hutchinson and Quintas, 2008).

Li et al. (2016) have demonstrated that business-IT governance, operational and business processes and strategic mechanisms result in a substantial increase in firm performance when they are inter-related with the synergies between managerial, strategic and operational components (acumens) are likely to be stronger for SMEs (Ghobadian and O'Regan, 2002).

Strategic acumen of knowledge relates to the alignment between business and IT knowledge, which is essential in realizing full value from digitization (Tallon, 2008) and improving business value creation. It constitutes firms' ability to invest in knowledge and understand where this investment should occur and what elements of knowledge and skills need to be allocated between IT and business functions of a firm (Avolio et al. 2014; Belitski and Liversage, 2019). 
Strategic knowledge aims to make a firm more attractive to externals collaborators and partners and share knowledge within and outside organizational boundaries.

Managerial acumen of knowledge includes the manager's understanding of structures and processes within the organization and how to engage with external partners (Del Giudice and Maggioni, 2014; Del Giudice et al. 2017). The managerial component of knowledge includes allocating functions and tasks to business and IT departments and investment in the C-level managers to train their skills. This knowledge component is also responsible for the development of a business model and deploy innovative solutions within a firm and in inter-organizational contexts (Korte and Hüsing, 2015).

Operational acumen of knowledge relates to the development and enhancement of processes in both IT and business infrastructures. It is involved in supporting the development of new products by technologically enabling communication between the departments within a firm and with external collaborators (Lee and Weidong, 2010; Avolio et al. 2014). This may or may not include digital means (Markus and Tanis, 2000).

Strategic acumen, for example, deals with knowledge identification and activities that help to identify the knowledge necessary for an SME, as well as where the knowledge can be sourced from (Egbu et al., 2005). Management acumen refers to approach and knowledge creation mechanisms, for example, giving SME's members time to experiment with new knowledge and develop a synthesis of existing and new technologies (Gupta and Govindarajan, 2000; Li et al. 2016). Operational acumen relates various sources of knowledge and refers to implementing internally produced knowledge and external sources for production, including technology adoption and storage, retention of knowledge, and matching various technologies and systems together. This may also include the processes of the documentation and codification of 
information and informing departments within the SMEs on each technology's functionality.

(Wong and Aspinwall, 2004, 2005).

Altogether three acumens of knowledge relate to organizational ambidexterity as an ability of SMEs to pursue two and more competing knowledge development activities simultaneously, such as manufacturing efficiency and flexibility (Soto-Acosta et al. 2018). These three mechanisms represent how three different functions of an organization, often competitive due to limited resources in SMEs, can rely on both internal capabilities and inter-organizational collaboration.

The three acumens enable knowledge creation internally and sourcing from external sources, accumulation, and implementation that involve sharing strategies, customers, suppliers, resources to develop new products, and increase firm's performance (Del Giudice and Maggioni, 2014; Sarala, Cooper, Junni and Tarba, 2016). All three acumens demonstrate the range of strategic choices in structure, process, and strategic relational mechanisms. We formulate our baseline hypothesis:

H1: Strategic, managerial, and operational acumens of knowledge complexity directly facilitate firm performance.

\subsection{Resilience and firm performance}

Firms rely on their own as well as external resources, establishing transactions that involve sharing knowledge with customers, suppliers, competitors, enterprise groups, and government. In particular, SMEs draw on limited financial resources to new products and sell them. These transactions make firms more agile and resilient to better meet market demands in a VUCA environment (Teece et al. 2016). For knowledge transactions to lead to innovation, growth, and 
productivity, factors that contribute to absorptive capacity may also drive firm resilience. Firms that are more resilient and have greater dynamic capabilities than their competitors in a market (Kothari et al. 2013, Del Giudice and Maggioni, 2014) can better adapt to the changing environment and grow.

Resilience is an important characteristic of an organization that relates directly to their survival and leveraging external shocks, which leads to functioning in the market despite a relative lack of such competencies, time, and resources (Akgün and Keskin, 2014).

Organizational resilience is captured by the extent to which a firm is agile to external hostility, in particular, a firm is willing and able to stay in the market, sell, employ, and innovate in the face of uncertain external conditions and lack of strategic resources (Weber and Tarba, 2014). Securing a combination of strategic, managerial, and operational acumens of knowledge enables greater flexibility and diversification, including the ability to be agile and change the market (Tanriverdi, 2005).

While lacking skills, time, and budget, a firm's ability to strategically use internal and external knowledge, manage it, and support operational infrastructure becomes important to persevere a firm's growth and productivity (Akgün and Keskin, 2014). Firm resilience will positively moderate the relationship between all three acumens of knowledge complexity and firm performance. We hypothesize:

H2: Firm resilience positively moderates the relationship between a) Strategic acumen of knowledge and firm performance; b) Managerial acumen of knowledge and firm performance; c) Operational acumen of knowledge and firm performance.

\section{Data and method.}




\subsection{Sample and estimation approach}

The empirical analysis is based on a novel dataset constructed via Empirica e-leadership online survey data (Korte and Husling, 2015; Empirica, 2015) collected as part of the eleadership: leading SME European Project sponsored by the European Commission in 2015. The data collected in the first survey was the first attempt for generating statistics on technology adoption and digital leadership skills in European SMEs, which are not collected by official statistics or by companies themselves. The online survey generated a comparatively small dataset that could be plagued by a non-response bias or information disclosure bias.

The authors have thoroughly reviewed the data. Additional unique features of the survey include sampling for representativeness at the level of regions in each country (at least one company in each country region and one in capital-city), firm stage ownership (a balanced number of start-ups/mature firms), firm size (micro, small and medium firms) and sector (at least

4 different sectors within each country were targeted). The industries would include education, ICT, utility, services, manufacturing, among others.

SMEs were selected by the partner organizations in Belgium, the UK, Denmark, Spain, and Bulgaria using the following criteria: firm size (SMEs), sector (any), technology adoption (firms that adopted at least three out of six digital technologies available in 2012-2014), firm was acknowledged as a leader by the third party (SME award, innovation leadership award, publication in a national press, national and European competition winner).

Empirica, together with its partners on the project, has collected email and telephone information for the 10,105 SMEs across 12 sectors and 5 countries during 2012-2015 with webpages by the script with the help of the Phython program. The records could generally be found 
by typing their full name of a firm. Of the 10,105 SMEs identified and emailed, 2,603 responded. This means the initial response rate was 25.75 percent. Only a subsample of observations were defined as digital technology active (used at least three of the six technologies mentioned in the survey) and provided firm sales and employment information. As this might cause a selection bias, regressions based on such survey responses are commonly estimated using a two-stage approach (Heckman, 1979). The subsequent second stage includes a control for unobserved determinants of selection estimated in the first stage (Crépon et al., 1998). Consequently, when a firm does not disclose sales or employment (productivity) it may mean they have sales but do not wish to disclose it or do not know their own sales. It would be incorrect to exclude these observations because the estimation of specific SMEs may be biased, because the firm is not properly identified by income. In the approach used here (Figure 2), both biases have to be accounted for. To address the disclosure bias, we conducted a probit regression on all 2,603 individuals identified:

Selection step one $: \operatorname{Pr}\left(\right.$ Disclosure $\left.=1 \mid x_{i}^{1}\right)=\Phi\left(x_{i}^{1} \beta\right)$

where $x_{i}^{1}$ contains the variables capturing firm characteristics such as age, industry and the type of technology used, geographical location in a region and country. We also include country and year fixed effects. Based on this regression, the Inverse Mill's ratio was calculated. It is included in the final outcome regression to control for the disclosure of sales and productivity information selection bias, also known as independence bias (Herstad and Ebersberger, 2015).

By restricting this analysis to the 271 firms where the SMEs participated in both 2015 and 2020 surveys and all report sales and employment (positive or zero) and well as what combination of digital technology they use, it is possible to use the additional information available from the survey to estimate the likelihood of a firm to be active or not active in sales 
and technology adoption. There is a group of SMEs which are involved in at least one technology adoption, but report no sales and these were not included in the model. For those observations we define a "technology active" bias. We conducted a probit regression on 271 SMEs identified:

Selection step two: $\operatorname{Pr}\left(\right.$ technology Active $\left.=1 \mid x_{i}^{2}\right)=\Phi\left(x_{i}^{2} \beta\right)$

where $x_{i}^{2}$ includes firm characteristics assumed to affect the decision to adopt technology, including country and year fixed effects, availability of resources such as employment, importance to competitiveness collaboration on IT apps and infrastructure in-house, on administration and operations processes in-house, collaboration on data in-house as well as the importance to competitiveness collaboration of using IT apps and infrastructure externally, administrative resources and operations externally and collaboration on data externally. Based on this selection regression a second Inverse Mill's ratio was calculated which was included in the final outcome regression. The correction of two selection biases by means of the three-step model employed here requires two instruments to produce credible estimates. In each stage, at least one variable has to determine selection without affecting the final or subsequent stages (Heckman, 1979). The results of the selection equations are reported in Table A1 in Appendix A. We organized the second (follow-up) survey for 271 SMEs that responded in the first round during July-October 2020 and referred to 2018-2020. Both survey waves aimed to evaluate firm performance characteristics, level of skills, competencies, IT investment across various technologies and priorities, efficiency in operational and strategic components, and other firm-level characteristics, including industry and country. 
The repeated - follow-up survey in 2020 was sent to 271 SMEs who were preselected from the first survey in five countries, with 102 firms responding to the second survey wave. Table 1 provides descriptive statistics for two samples of 2015 and 2020.

As a result, the third stage's final model includes 102 SMEs that responded to both surveys in 2015 and 2020. Our estimation strategy is introduced in Figure 1.

Table 1 about here

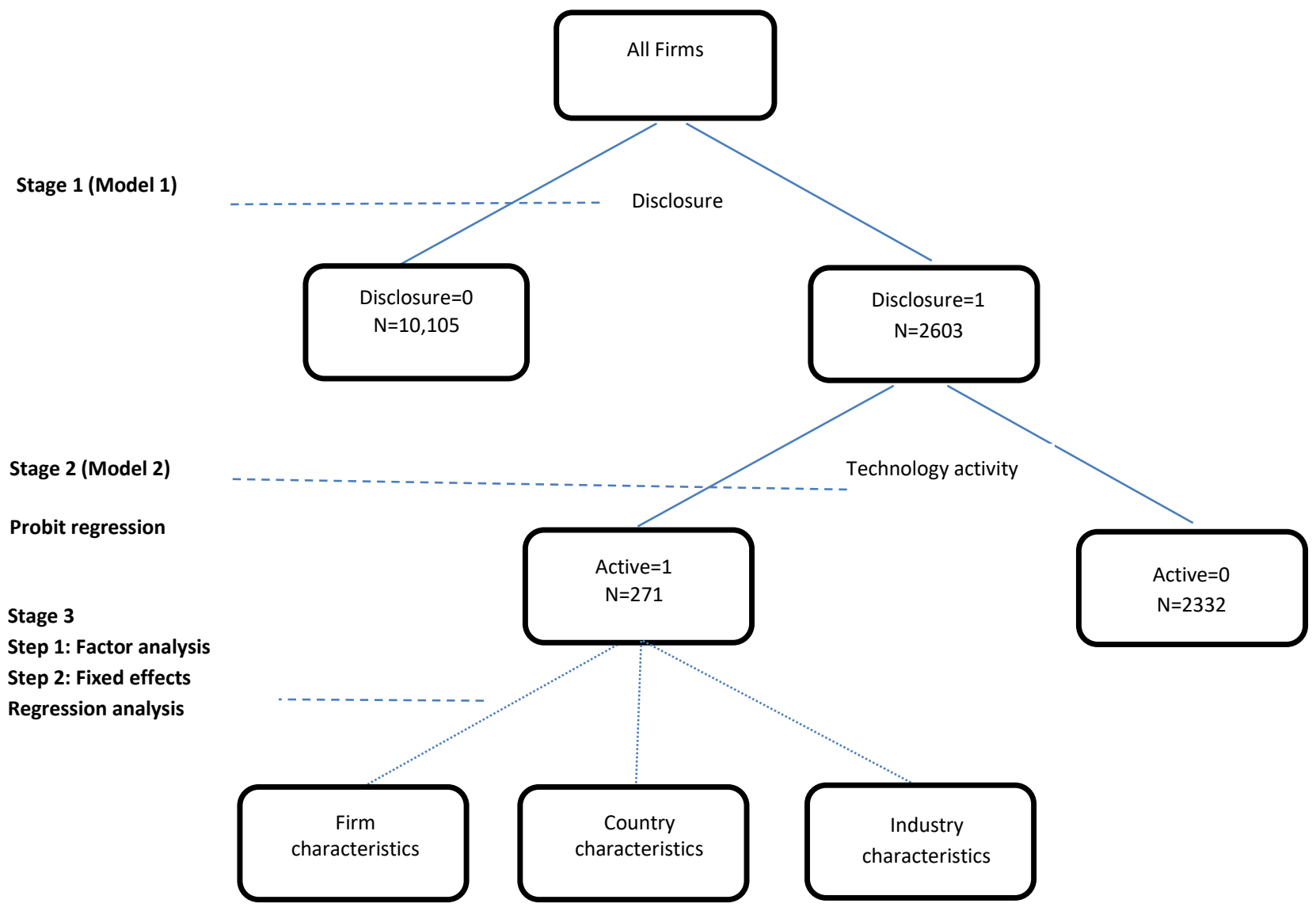

Figure 1: Estimation strategy

\subsection{Factor analysis}


The third stage of the estimation approach consists of two steps and deals with 102 SMEs surveyed in 2015 and 2020. The first step includes the exploratory factor analysis to generate composite indicators of the knowledge complexity acumens pulled together in two surveys and used as explanatory variables for stage three. The second step includes panel data regression analysis using 102 firms and 204 observations from both surveys.

We start by drawing on the inter-relationship concept between the elements that constitute each acumen of knowledge complexity. Each element and mechanism that enables each acumen of knowledge to exist and grow interacts with other acumen elements and with other elements in other acumens of knowledge. A specific technique could be used to understand and test the meaningful groups of elements with shared co-movements with one another. To construct the composite factors of acumens, we need to start by analyzing all potential combinations of mechanisms responsible for knowledge related to strategy, management, and operations in a firm. After the process of forming acumens has been completed, a pattern of a relationship within each acumen will appear, which enables one to position it within three acumens: Strategic, Operational, and Managerial. In complex organizational systems, it is possible for the mutual consistent ecology of parts, which emerges from the decentralized system (Maguire et al. 2011). We propose a model that brings together all three acumens and manifests the relationship between each of the acumens and firm performance.

Formation of acumens requires a reduction in the number of interactions and allows reduction means that the goal is to simplify by summarizing the variance associated with several firm-level characteristics - 33 elements of a system down six-factor loadings retained by the estimation of factor analysis with the threshold greater than 1. 
This exercise enabled us, bringing the number of interactions from 1056 (33(33-1)) to 30 interactions (6(6-1)). The goal of reducing complexity and capturing the major share of the interactions between elements. This approach enables a better understanding of how elements interact within the knowledge complexity. This approach can incorporate the interactions of multiple forces and various ways that respectively best describe the organization's environment (Bennis and Nanus, 1985).

Drawing on information from Table 2 - Rotated Factor Loading, which illustrates the factors associated with the respective variables that compose them we named each factor representing what major impacts it constitutes within-Strategic, Managerial, and Operational acumens. From the Rotated factor loading (pattern matrix), six factors were retained.

Table 2 about here

\subsection{Regression analysis}

Dependent variables

We use two variables as firm performance measures - firm sales growth and firm productivity growth during 2012-2014 and 2018-2020. Firm sales is defined as a total revenue change over the past three years. Firm productivity is defined as a total change in the revenue to employment ratio over the past three years.

\section{Explanatory and control variables}

To build the exploratory and control variables, we use factor analysis with the online survey responses. Our pattern matrix offers a clearer picture of the relevance of each variable in the factor loadings. The higher the load, the more relevant in defining the factor's dimensionality. Based on these criteria and a 0.6 threshold, six factors were 
identified (Table 2). The rotation oblique promax, which produces orthogonal factors and normalized around zero, although they vary from negative values - lack of factors to positive - the abundance of a factor in a firm.

Our main control variables are initial employment, full-time employees in 2012 and 2018, and product change. We add 2-digit industry fixed effects and country fixed effects to control for unobserved heterogeneity across industries and countries.

We also add product change by an organization (in months), which measures a degree of upgrading products and services with new ones to measure innovativeness of business model and new product introduction to the market. Descriptive statistics are presented in Table 3.

Table 3 about here

The third stage (step two) includes panel data estimation with country and industry fixed effects to estimate the effect of the three acumens of knowledge complexity on firm performance. The results of the estimation are presented in Table 4. We control for potential disclosure bias and technology adoption bias by using two Mills ratios produced in the prior two steps (see Table A1 in Appendix A).

\section{Results}

Table 4 (specifications 1-3) illustrates the interaction effect of knowledge complexity (each acumen) and resilience on sales growth, while (specifications 4-6) illustrate the cumulative effect of knowledge and resilience on productivity (sales to workers ratio).

Table 4 about here 
We partly support $\mathrm{H} 1$, which demonstrated that Managerial and Operational acumens of knowledge complexity are positively associated with SME's sales growth and performance. Factor 1 "Managerial Skills" associated with executives involved in IT investment and management decision-making, exploitation of new trends, innovating business models and change management as well as deploying innovative IT apps and solutions, positively affects firm sales and productivity.

One standard deviation increase in factor "skills" is associated between 18.18 and $22.12 \%$ change in sales growth, $\mathrm{p}<0.05$ and between 0.20 to 0.27 productivity change, $\mathrm{p}<$ 0.05 (specification 2-3, Table 4). Managerial skills enable more efficient alignment between business and IT and are conducive to efficiency.

We found that factor 6 "Inter-organizational collaboration" that relates to collaboration in IT apps and infrastructure with external partners, collaboration on administration and operations externally as well as collaboration on data analysis and exchange externally, is positively associated with firm sales and performance. One standard deviation increase in factor "Collaboration" is associated with 8.89-9.98\% change in sales growth, $\mathrm{p}<0.10$ and between 0.10 to 0.11 firm productivity change, $\mathrm{p}<0.05$ (specification 5-6, Table 4). Our finding supports the crucial role of the development of inter-organizational collaboration for dynamic capabilities (Teece, Pisano, and Shuen, 1997; Kothari et al. 2013; Audretsch and Belitski, 2020).

We found that factor 4, "Resilience" is not associated with sales growth but negatively associated with firm productivity $(\beta=-0.07-(-0.08), \mathrm{p}<0.05)$ (specification $5-6$, Table 4). Resilience captures a mix of exogeneous and endogeneous shocks that affect the dynamics of a firm's ability to sells and hire (Del Giudice and Maggioni, 2014). 
Our $\mathrm{H} 2 \mathrm{~b}$, which states that resilience positively moderates the relationship between managerial skills and firm performance, is supported.

The cumulative effect of firm resilience and managerial skills increases firm sales by 46.67 percent $(\beta=22.12+20.55=42.67, \mathrm{p}<0.05)$ (specification 2-3, Table 4). The cumulative effect of firm resilience and managerial skills increases firm productivity by $0.71(\beta=0.32+0.39=0.71$, $\mathrm{p}<0.05$ ) (specification 5-6, Table 4). This result is both interesting and intriguing when interpreted in economic terms. A combination of managerial competencies and skills facilitates firm performance when a firm has developed an agile response to the VUCA environment (Bennis and Nanus, 1985; Buckley and Carter, 2002).

We do not support for $\mathrm{H} 2 \mathrm{c}$, by contrast we find strong negative effect of interorganizational collaboration on firm sales and performance with an increase in a level of firm's resilience. The moderation effect of firm resilience on inter-organizational collaboration - sales link is negative, decreasing sales by 1.99 percent $(\beta=9.13-7.14=1.99, p<0.05)$ (specification $2-3$, Table 4). The cumulative effect of firm resilience and inter-organizational collaboration decreases firm productivity by 0.06 percent $(\beta=0.13-0.07=0.06, \mathrm{p}<0.05)$ (specification $5-6$, Table 4). This finding demonstrates that the VUCA-environment when firms require resilience to stay in the market, sell, hire, and innovate, is negatively associated with returns to open innovation (West et al. 2014, 2019) and limits knowledge collaboration options (Roper et al. 2017; Audretsch and Belitski, 2019). Strategic acumen of knowledge complexity is not moderated firm resilience neither it directly affect performance in SMEs. This is an interesting finding, as it demonstrates that strategic acumen of knowledge is likely to be long-term and cannot capture cross-sectional effects with up to 2 years lag. Strategic acumen, however, may be important in complementing the managerial skills in a firm. In fact, it facilitates the effect of managerial 
acumen of knowledge on firm performance through firm resilience. Resilience is a part of the strategic knowledge complexity of a firm. That said, managerial acumen of a firm's knowledge complexity is of crucial importance to enhance the firm's resilience to external shocks and making the firm more agile for greater performance and sales (Tanriverdi, 2005; Kothari et al. 2013).

Inverse Mill's ratios for disclosure bias and technology activities are negative and statistically significant. This demonstrates that respondents who did not answer the question on sales and productivity as well as on technology adoption were not included in our final sample were less likely to participate in sales activity and adopt the technology.

Our analysis builds on the VUCA framework and the resource-based view to shed light on how three different knowledge complexity elements can influence firm sales and productivity, considering the moderating role of firm resilience to market shocks. This becomes particularly important during the pandemic when firms struggle to keep up their sales and resource suppliers within the new VUCA environment. Concerning the ICT context, the results revealed that operational capabilities related to the adoption of digital technologies positively affect firm performance (Kmieciak et al., 2012). Interestingly, that knowledge management component was the major driver of firm performance. The cumulative effect of firm resilience and managerial skills has been positive and significant for firm sales changes by 42.67 percent and productivity by 0.71 percent.

These findings are consistent with previous studies, suggesting that firm resilience and management resources, along with other critical resources such as IT capabilities and firm's strategy, may enhance firm performance, including sales, productivity, and innovation (Akgün and Keskin, 2014). Within the VUCA context, the results show that 
knowledge complexity management has a positive influence on organizational ambidexterity with altogether three acumens changing firm performance. This finding is consistent with existing studies analyzing the organizational antecedents of firm productivity and growth, which identify knowledge as the most strategic resource of SMEs with the potential to improve innovation (Soto-Acosta et al. 2018; Martinez-Conesa et al., 2017). Regarding the role of resilience, a negative relationship was found between managerial acumen and collaboration factor for SMEs on firm performance, which demonstrates the organizational substitutability and that collaboration with external partners can leverage the reduction in form performance and provide firm with additional resources (Audretsch and Belitski, 2019; Kobarg et al. 2019). At the same time, if external knowledge sourcing is limited, then greater resilience of SMEs is beneficial to leverage the VUCA environment.

\section{Discussion and Conclusion}

\section{Attendance to the Research Objectives}

This study answered the question: how three acumens of knowledge complexity (Buckley, 2002; Del Giudice and Maggioni, 2014; Jiménez-Jiménez, Martínez-Costa, and Sanz-Valle, 2014; Belitski et al. 2019) as well as firm resilience (Akgün and Keskin, 2014) affect firm sales and productivity in European SMEs.

\section{Attendance to the Research Methodology}

This study contributes to the methodology of knowledge complexity analysis, including in the context of VUCA and when the survey instrument is used to collect primary data, which can generate significant disclosure bias and affect the final result. WE introduced the method of collecting script data with the help of the Phython program with the records that could generally be found by typing their full name, firm, and industry. We also demonstrated that a subsample of 
SMEs' observations were defined as technologically active firms and provided information on sales as well as other firm activity characteristics. As this might cause a selection bias, regressions based on such survey responses are commonly estimated using a two-stage approach (Heckman, 1979). The subsequent second stage includes a control for unobserved determinants of selection estimated in the first stage (Crépon et al., 1998). Consequently, when an SME does not disclose sales, it may mean they have sales but do not wish to disclose it or that they do not know their own sales. It would be incorrect to exclude these observations because the estimation of specific individuals may be biased. We apply the two-stage approach to control how the knowledge complexity, resilience, and firm performance relationship can be affected by potential commercialization and technology adoption bias. The Mills ratios used for corrections were negative and statistically significant, which illustrated potential information bias in SMEs that do not report sales or technology adoption are less likely to have financial returns on complex knowledge systems and adopt the technology.

\section{Contributions to Theory}

Our contribution to knowledge management literature is in demonstrating using the organizational resilience and resource-based view perspective on how the interactions between various elements of strategic, managerial, and operational acumens of knowledge complexity change performance in SMEs.

We discover that SMEs' incentives should be focused on facilitating interorganizational collaboration and providing "soft support" in the time of agility and adversity. This is because the lack of resources significantly affects organizational resilience and potentially "locking in" SMEs potential. Interestingly we find that resilience 
may lead to "lock in" effect and reduce the intensity and quantity of collaborative linkages, affecting their performance. Policies that aim at R\&D collaborations between firms in both business and IT need to account for potential negative externalities and develop mechanisms to foster resilience and initiate R\&D collaboration programs in a VUCA environment for SMEs.

This study also emphasizes that the returns from inter-organizational collaboration as part of the operational acumen of knowledge complexity depend upon SME's ability to manage infrastructure, mobility, and data. The relationship is negatively moderated by firm resilience, which means that the most resilient firms may focus on exploiting internal resources and substituting it for inter-organizational collaboration. Secondly, this study demonstrates that SME's growth and productivity strategy should be management skills and competencies driven, rather than strategy-driven, with strategy facilitating managerial decision-making on business and IT.

\section{Management Implications}

Synergies between strategic, managerial, and operational acumen are important in facilitating firm sales and productivity. One of the most important mechanisms which facilitate the managerial acumen was found to be IT investment and management decision-making, exploitation of new ICT trends and markets, innovating business models and driving change management, innovating new mobility and digital technologies as well as use inter-disciplinary staff and knowledge to influence external stakeholders. The most relevant elements of the operational acumen of knowledge for SMEs' performance are various mechanisms and forms of inter-organizational collaboration such as collaboration on business and IT applications and infrastructure, administration and operations with data and information exchange, collaboration on data availability, accumulation and exchange. These elements of acumens are important to 
minimize the effect of VUCA externalities, which may arise in SMEs, given their shortage of knowledge and resources. We emphasize for managers to consider communication approaches with external partners and synchronize operations on business and IT, which can minimize the potentially negative effect of uncertain environment and overcome lack of resources.

European SMEs are likely to depend on horizontally aligned organizational governance mechanisms with specialists and digital leaders switching their roles (Avolio et al. 2014; Korte and Hüsing, 2015).

Our findings also draw manager's attention to the importance of sharing managerial and strategic knowledge components with external partners (West and Bogers, 2017) in interrelated collaboration.

\section{Limitations and Future Studies.}

One of the limitations of this study is that SMEs are expected to face more problems in achieving organizational ambidexterity with all three acumens, as they have restricted managerial expertise, less structured procedures, and fewer resources than larger firms (Soto-Acosta et al. 2018). Further study may focus on adding more firm characteristics that demonstrate SME's resource limitations, making it more challenging for SMEs to efficiently allocate knowledge and increase firm performance. Future research may want to use longitudinal data with longer lags to enforce the causality dimension in knowledge complexity and firm performance research.

In addition to regression analysis, which is limited in answering "how" and "why" knowledge complexity is managed within, and outside a firm, future research will consider a mixed-method approach of both interviews with high growth SMEs and online surveys. 
To unveil the role that firm resilience plays in SMEs in the VUCA environment, future research may focus specifically on SMEs that lack resources, skills, and time but continue innovating, commercializing new knowledge, and creating new jobs (Teece et al. 2016). In doing so, future research should be able to offer an in-depth understanding of how resources could be orchestrated in all three acumens to spur productivity and sales in SMEs.

\section{References}

Akgün, A. E., and Keskin, H. (2014). “Organisational resilience capacity and firm product innovativeness and performance”. International Journal of Production Research, Vol. 52 No. 23, pp. 6918-6937.

Audretsch, D.B., and Feldman, M.P. (1996). "R\&D spillovers and the geography of innovation and production". The American economic review, Vol. 86. No. 3, pp. 630-640.

Audretsch, D. B. and Belitski, M. (2019). "The limits to collaboration across four of the most innovative UK industries". British Journal of Management.

Audretsch, D. B., and Belitski, M. (2020). "The role of R\&D and knowledge spillovers in innovation and productivity". European Economic Review, 123, 103391.

Avolio, B. J., Sosik, J. J., Kahai, S. S., and Baker, B. (2014). "E-leadership: Re-examining transformations in leadership source and transmission". The Leadership Quarterly, Vol. 25 No. 1, pp. 105-131.

Barney, J. B. (1991). "Firm Resources and Sustained Competitive Advantage," Journal of Management, Vol. 17, No. 1, pp. 99-120.

Belitski, M. (2019). "Innovation in Schumpeterian-type firms: Knowledge collaboration or knowledge spillover?”. Foundations and Trends® in Entrepreneurship, Vol. 15 No. 3-4, pp.368390.

Belitski, M., and Liversage, B. (2019). "E-Leadership in small and medium-sized enterprises in the developing world". Technology Innovation Management Review, Vol. 9 No. 1, pp. 64-74.

Beijerse, R.P. (2000), “'Knowledge management in small and medium-sized companies: knowledge 162-79.

management for entrepreneurs", Journal of Knowledge Management, Vol. 4 No. 2, pp. \& Row.

Bennis, W., Nanus, B. (1985), Leaders: Strategies for Taking Charge, New York: Harper Brunswicker, S. and Vanhaverbeke, W. (2015). "Open innovation in small and medium-sized enterprises (SMEs): External knowledge sourcing strategies and internal organizational facilitators". Journal of Small Business Management, Vol. 53. No. 4, pp. 1241-1263.

Buckley, P. J. (2002). Is the international business research agenda running out of steam?. Journal of international business studies, 33(2), 365-373.

Buckley, P. J., \& Carter, M. J. (2002). Process and structure in knowledge management practices of British and US multinational enterprises. Journal of International Management, 8(1), 29-48. 
Cavusgil, S.T. and Knight, G. A. (2015), "The born global firm: An entrepreneurial and capabilities perspective on early and rapid internationalization", Journal of International Business Studies, Vol. 46, pp. 3-16.

Chakravarthy, B. (1997), "A new strategy framework for coping with turbulence", Sloan Management Review, Winter, pp. 69-82.

Cheng, J.H. and Fu, Y.C., (2013), "Inter-organizational relationships and knowledge sharing through the relationship and institutional orientations in supply chains", International Journal of Information Management, Vol. 33, pp. 473- 484.

Crépon, B., Duguet, E. and Mairessec, J. (1998). "Research, Innovation and Productivity: An Econometric Analysis at The Firm Level". Economics of Innovation and new Technology, Vol. 7. No. 2, pp. 115-158.

Curran, J. and Blackburn, R.A. (2001), Researching the Small Enterprise, Sage, London.

Del Giudice, M., \& Maggioni, V. (2014). Managerial practices and operative directions of knowledge management within inter-firm networks: a global view. Journal of Knowledge Management, 18(5), 841-846.

Del Giudice, M., Carayannis, E. G., \& Maggioni, V. (2017). Global knowledge intensive enterprises and international technology transfer: emerging perspectives from a quadruple helix environment. The Journal of Technology Transfer, 42(2), 229-235.

Dyer, J. H., Singh, H. (1998), "The relational view: Cooperative strategy and sources of interorganizational competitive advantage", Academy of Management Review, Vol. 23, pp. 660679.

Durst, S., and Edvardsson, I. R. (2012). Knowledge management in SMEs: a literature review. Journal of Knowledge Management, Vol. 16 no 6, pp. 879-903,

Empirica (2015) e-leadership online survey data and follow up survey 2020. Available at: https://empirica.com/de/themes/eskills-work/e-leadership/

Egbu, C.O., Hari, S. and Renukappa, S.H. (2005), 'Knowledge management for sustainable competitiveness in small and medium surveying practices', Structural Survey, Vol. 23 No. 1, pp. 7-21.

Ghobadian, A., and O'Regan, N. 2002. "The link between culture, strategy and performance in manufacturing SMEs", Journal of General Management, Vol. 28 no. 1, pp. 1635 .

Gupta, A.K. and Govindarajan, V. (2000), “Knowledge management's social dimension: lessons from Nucor Steel', Sloan Management Review, Vol. 42 Nos 1, Fall, pp. 71-80.

Hargadon, A. and Sutton, R. 1997. Technology brokering and innovation in a product development firm. Administrative Science Quarterly, Vol. 42, pp. 716-749.

Heckman, J. J. (1979). Statistical models for discrete panel data. Chicago, IL: Department of Economics and Graduate School of Business, University of Chicago.

Hutchinson, V. and Quintas, P. (2008), “Do SMEs do knowledge management? Or simply manage what they know?', International Small Business Journal, Vol. 26 No. 2, pp. 131-54 Jaffe, A. B. (1989). "Real Effects of Academic Research". American Economic Review, Vol. 79. No. 5, pp. 957-970

Jiménez-Jiménez, D., Martínez-Costa, M., \& Sanz-Valle, R. (2014). Knowledge management practices for innovation: a multinational corporation's perspective. Journal of Knowledge Management, Vol. 18 No. 5, pp. 905-918. 
Kmieciak, R., Michna, A. and Meczynska, A. (2012), "Inovativeness, empowerment and IT capability: evidence from SMEs”, Industrial Management \& Data Systems, Vol. 112 No. 5, pp. 707-728.

Kobarg, S., Stumpf-Wollersheim, J., and Welpe, I. M. (2019). More is not always better: Effects of collaboration breadth and depth on radical and incremental innovation performance at the project level. Research Policy, Vol. 48 No. 1, pp. 1-10.

Korte, W., and Hüsing, T. (2015). "e-Leadership - Digital Skills for SMEs". The European Commission, DG Enterprise and Industry. Available at: http://eskills-lead.eu/documents

Kotabe M., Jian C., and Murray J. (2014), "Examining the complementary effect of political networking capability with absorptive capacity on the innovative performance of emerging market firms", Journal of Management, Vol. 43 No. 4, 1131-1156.

Kothari, T., Kotabe, M., \& Murphy, P. (2013). "Rules of the game for emerging market multinational companies from China and India". Journal of International Management, 19(3), 276-299.

Laursen, K. and Salter, A.J. (2014). "The paradox of openness: Appropriability, external search and collaboration”, Research Policy, Vol. 43. No. 5, pp. 867-878.

Lee, G. and Weidong, X. (2010). "Toward agile: an integrated analysis of quantitative and qualitative field data on software development agility" MIS Quarterly Vol. 34 No. 1, pp. 87-114.

Leidner, D., Lo, J., and Preston, D.S. (2011). "An Empirical Investigation of the Relationship of IS Strategy with Firm Performance”. Journal of Strategic Information Systems, Vol. 20 No. 4, pp. 419-437.

Li, W., Liu, K., Belitski, M., Ghobadian, A., and O'Regan, N. (2016). ”e-Leadership through strategic alignment: An empirical study of small-and medium-sized enterprises in the digital age". Journal of Information Technology, 31(2), 185-206.

Martinez-Conesa, I., Soto-Acosta, P. and Carayannis, E.G. (2017), "On the path towards open innovation: assessing the role of knowledge management capability and environmental dynamism in SMEs", Journal of Knowledge Management, Vol. 21 No. 3, pp. 553-570

McAdam, R. and Reid, R. (2001), "SME and large organisation perceptions of knowledge management: comparisons and contrasts", Journal of Knowledge Management, Vol. 5 No. 3, pp. 231-41.

Maguire, S., Allen, P., and McKelvey, B. (2011). "Complexity and management: Introducing the SAGE handbook," The SAGE handbook of complexity and management, pp. 126.

Markus, M. L., \& Tanis, C. (2000). “The enterprise systems experience-from adoption to success. Framing the domains of IT research: Glimpsing the future through the past, Vol. 173, pp. 207-173.

Merritt, T. P. (1974), "Forecasting the future business environment - The state of the art", Long Range Planning, Vol. 7, No. 3, pp. 54-62.

Mueller, V., Rosenbusch, N., and Bausch, A. (2013). "Success patterns of exploratory and exploitative innovation: A meta-analysis of the influence of institutional factors". Journal of Management, Vol. 39, pp. 1606-1636.

Oliva, F.L. (2014), "Knowledge management barriers, practices and maturity model", Journal of Knowledge Management, Vol. 18 No. 6, pp. 1053-1074.

Oliva, F., Couto, M., Santos, R. and Bresciani, S. (2018), "The integration between knowledge management and dynamic capabilities in agile organizations", Management Decision, ttps://doi.org/10.1108/MD-06-2018-0670. 
Oliva, F. and Kotabe, M. (2019), "Barriers, practices, methods and knowledge management tools in startups", Journal of Knowledge Management, https://doi.org/10.1108/JKM-06-2018-0361.

Roper, S., Love J., and Bonner, K. (2017). "Firms' knowledge search and local knowledge externalities in innovation performance". Research Policy, Vol. 46, pp. 43-56.

Sarala, R.M., Cooper, C., Junni, P., and Tarba, S. (2016), “A socio-cultural perspective on knowledge transfer in mergers and acquisitions", Journal of Management, Vol. 42 No. 5, 12301249.

Shams, S. R., Vrontis, D., Weber, Y., Tsoukatos, E., \& Ferraris, A. (Eds.). (2019). Crossfunctional Knowledge Management: The International Landscape. Routledge.

Soto-Acosta, P. and Cegarra-Navarro, J.G. (2016), "New ICTs for knowledge management in organizations", Journal of Knowledge Management, Vol. 20 No. 3, pp. 417-422.

Soto-Acosta, P., Popa, S., \& Martinez-Conesa, I. (2018). Information technology, knowledge management and environmental dynamism as drivers of innovation ambidexterity: a study in SMEs. Journal of Knowledge Management, Vol. 22 No. 4, pp. 931-948,

Spender, J. C.; Corvello, V.; Grimaldi, M. and Rippa, P. (2017), "Startups and open innovation: a review of the literature", European Journal of Innovation Management, v. 20, n. 1, pp.4-30.

Tallon, P. P. (2008). “A Process-Oriented Perspective on the Alignment of Information Technology and Business Strategy," Journal of Management Information Systems, Vol. 24 No 3, pp. 231-272.

Tanriverdi, H. (2005). "Information technology relatedness, knowledge management capability, and performance of multibusiness firms," MIS Quarterly, Vol. 29 No. 2, pp 311-334.

Teece, D. J., Peteraf, M. and Leih, S. (2016), "Dynamic capabilities and organizational agility: risk, uncertainty, and strategy in the innovation economy", California Management Review, Vol. 58 No. 4, pp. 13-35.

Teece, D. J., Pisano, G. and Shuen, A. (1997), "Dynamic capabilities and strategic management”, Strategic Management Journal, Vol. 18 No. 7, pp. 509-533.

Usman, M., Roijakkers, N., Vanhaverbeke, W., and Frattini, F. (2018). "A systematic review of the literature on open innovation in SMEs". Researching Open Innovation in SMEs.

van de Vrande, V., J. de Jong, W. Vanhaverbeke, de Rochemont, M. (2009). "Open Innovation in SMEs: Trends, Motives and Management Challenges". Technovation, Vol. 29, No 6-7, pp.423-437

Van Beers, C. and Zand, F. (2014). "R\&D cooperation, partner diversity, and innovation performance: an empirical analysis". Journal of Product Innovation Management, Vol 31. No. 2, pp. 292-312.

Vahter, P., Love, J. H., Roper, S. (2014). “Openness and innovation performance: are small firms different?”. Industry and Innovation, Vol.21. No. 7-8, pp. 553-573.

von Hippel, E. (2005). “Democratizing Innovation”. MIT Press: Cambridge, MA.

Weber, Y. and Tarba, S. Y. (2014). "Strategic agility: a state of the art", California Management Review, Vol. 56, No. 3, pp. 5-12.

West, J., Salter, A. Vanhaverbeke, W. and Chesbrough, H. (2014). “Open innovation: The next decade"", Research Policy, Vol. 43 No. 5, pp. 805-811.

West, J. and Bogers, M. (2017). "Open innovation: current status and research opportunities”. Innovation, Vol. 19. No 1, 43-50.

Wong, K.Y. and Aspinwall, E. (2005), "An empirical study of the important factors for knowledge-management adoption in the SME sector', Journal of Knowledge Management, Vol. 
9 No. 3, pp. 64-82. Wong, K.Y. and Aspinwall, E. (2004), “Characterizing knowledge management in the small business environment', Journal of Knowledge Management, Vol. 8 No. 3, pp. 44-61.

Yoon, E. and Hughes, S. (2016), "Big Companies Should Collaborate with Startups", Harvard Business Review, Boston. 
Table 1. Sample distribution by country, industry, age and size

\begin{tabular}{|c|c|c|c|c|c|c|}
\hline Survey period & \multicolumn{3}{|c|}{$2012-2014(\mathrm{~N}=102)$} & \multicolumn{3}{|c|}{$2018-2020(\mathrm{~N}=102)$} \\
\hline Criteria & $\begin{array}{c}\text { Share in } \\
\text { total }\end{array}$ & $\begin{array}{c}\text { Sales } \\
\text { growth, } \%\end{array}$ & $\begin{array}{l}\text { Productivity } \\
\text { ratio }\end{array}$ & $\begin{array}{c}\text { Share in } \\
\text { total }\end{array}$ & $\begin{array}{c}\text { Sales } \\
\text { growth, \% }\end{array}$ & $\begin{array}{l}\text { Productivity } \\
\text { ratio }\end{array}$ \\
\hline \multicolumn{7}{|c|}{ Country } \\
\hline Belgium & 14.56 & 11.17 & 0.1 & 14.56 & 11.47 & 0.11 \\
\hline Bulgaria & 17.48 & 26.96 & 0.16 & 17.48 & 21.16 & 0.17 \\
\hline Denmark & 31.07 & 9.78 & 0.07 & 31.07 & 11.1 & 0.11 \\
\hline Spain & 19.42 & 13.61 & 0.17 & 19.42 & 11.51 & 0.19 \\
\hline United Kingdom & 17.48 & 41.81 & 0.38 & 17.48 & 35.80 & 0.25 \\
\hline \multicolumn{7}{|c|}{ Industry } \\
\hline ICT Services & 6.86 & 21.32 & 0.19 & 6.86 & 24.3 & 0.22 \\
\hline Nonprofit & 7.84 & 13.10 & 0.10 & 7.84 & 13.50 & 0.08 \\
\hline Government & 10.78 & 25.01 & 0.15 & 10.78 & 0.20 & 0.15 \\
\hline Healthcare & 14.71 & 62.01 & 0.36 & 14.71 & 41.20 & 0.31 \\
\hline Financials & 11.76 & 31.82 & 0.19 & 11.76 & 30.20 & 0.10 \\
\hline Utilities and Energy & 13.73 & 23.33 & 0.31 & 13.73 & 15.02 & 0.14 \\
\hline Industrials \& Manufacturing & 10.78 & 6.75 & 0.05 & 10.78 & 5.15 & 0.06 \\
\hline Consumer Goods Retail & 6.86 & 6.88 & 0.04 & 6.86 & 25.20 & 0.09 \\
\hline Services & 4.90 & 44.62 & 0.40 & 4.90 & 21.12 & 0.20 \\
\hline Education & 11.76 & 12.57 & 0.13 & 11.76 & 10.77 & 0.15 \\
\hline \multicolumn{7}{|c|}{ Firm Age } \\
\hline Early growth firm & 47.76 & 43.02 & 0.36 & 38.75 & 28.12 & 0.28 \\
\hline Mature firm (>7 years) & 52.24 & 9.51 & 0.08 & 32.25 & 11.21 & 0.12 \\
\hline \multicolumn{7}{|c|}{ Firm Size } \\
\hline micro & 50.98 & 22.8 & 0.26 & 50.98 & 21.80 & 0.21 \\
\hline small & 34.31 & 39.79 & 0.26 & 34.31 & 25.20 & 0.24 \\
\hline medium & 14.71 & 7.73 & 0.06 & 14.71 & 11.34 & 0.09 \\
\hline
\end{tabular}

Source: Empirica e-leadership online survey data (2014) and follow up survey 2020 
Table2. Rotated factor loading (pattern matrix) and Cronbach alpha

\begin{tabular}{|c|c|c|c|c|c|c|c|c|}
\hline \multirow[b]{2}{*}{ Survey questions used } & \multirow[b]{2}{*}{$\begin{array}{l}\text { Knowledge } \\
\text { acumen }\end{array}$} & \multicolumn{7}{|c|}{ Factor loadings } \\
\hline & & $\begin{array}{c}\text { F1- } \\
\text { Skills }\end{array}$ & $\begin{array}{c}\text { F2- } \\
\text { Infrastructure }\end{array}$ & $\begin{array}{c}\text { F3- IT } \\
\text { coordination }\end{array}$ & $\begin{array}{c}\text { F4- } \\
\text { Resilience }\end{array}$ & $\begin{array}{c}\text { F5- } \\
\text { Mobility }\end{array}$ & $\begin{array}{c}\text { F6- } \\
\text { Collabo- } \\
\text { ration. }\end{array}$ & Uniqueness \\
\hline \% IT Budget spent on developing new apps 2012 & Strategic & 0.06 & -0.03 & 0.09 & 0.21 & 0.66 & 0.18 & 0.49 \\
\hline $\begin{array}{l}\% \text { of total IT budget spent on cloud-based } \\
\text { services } 2012\end{array}$ & Strategic & -0.07 & -0.06 & -0.09 & -0.11 & 0.11 & 0.17 & 0.46 \\
\hline $\begin{array}{l}\% \text { of total IT budget spent on Mobile devices and } \\
\text { apps } 2012\end{array}$ & Strategic & -0.07 & 0.02 & -0.12 & 0.17 & 0.24 & 0.36 & 0.60 \\
\hline $\begin{array}{c}\text { last year, how many days per employees spent on } \\
\text { trainings? }\end{array}$ & Operational & 0.07 & 0.12 & 0.15 & -0.10 & 0.55 & -0.16 & 0.60 \\
\hline $\begin{array}{l}\text { last year how many days per employees spent on } \\
\text { trainings from HEI? }\end{array}$ & Operational & 0.07 & -0.21 & -0121 & -0.13 & 0.06 & 0.26 & 0.43 \\
\hline enterprise has CIO (CTO) employed & Strategic & 0.28 & 0.55 & -0.12 & 0.18 & 0.07 & 0.36 & 0.47 \\
\hline $\begin{array}{l}\text { next } 2 \text { years invest in training in Apps } \\
\text { development/Software construction }\end{array}$ & Strategic & 0.29 & 0.13 & -0.15 & -0.40 & 0.70 & -0.06 & 0.38 \\
\hline $\begin{array}{c}\text { next } 2 \text { years invest in training in Business } \\
\text { Processes Management }\end{array}$ & Strategic & -0.19 & 0.03 & 0.15 & 0.17 & 0.61 & 0.19 & 0.40 \\
\hline $\begin{array}{l}\text { next } 2 \text { years invest in training in Bus } \\
\text { Development, Sales and Marketing }\end{array}$ & Strategic & -0.09 & 0.03 & 0.18 & 0.12 & -0.33 & -0.18 & 0.58 \\
\hline $\begin{array}{c}\text { next } 2 \text { years invest in orchestrating synergies } \\
\text { across business units }\end{array}$ & Operational & 0.09 & -0.03 & 0.18 & -0.11 & 0.44 & 0.17 & 0.61 \\
\hline $\begin{array}{l}\text { Importance to competitiveness collaboration on } \\
\text { IT apps \& infrastructure in-house }\end{array}$ & Operational & 0.19 & 0.02 & 0.72 & 0.64 & 0.26 & 0.27 & 0.19 \\
\hline $\begin{array}{l}\text { Importance to competitiveness collaboration on } \\
\text { admin \& operations processes in-house }\end{array}$ & Operational & 0.09 & 0.02 & 0.71 & -0.16 & -0.11 & 0.0 & 0.31 \\
\hline $\begin{array}{l}\text { Importance to competitiveness collaboration on } \\
\text { data in-house }\end{array}$ & Operational & 0.09 & 0.02 & 0.90 & 0.12 & 0.10 & 0.03 & 0.14 \\
\hline $\begin{array}{c}\text { Importance to competitiveness collaboration IT } \\
\text { apps and infrastructure externally }\end{array}$ & Operational & -0.02 & 0.08 & 0.21 & 0.26 & 0.14 & 0.71 & 0.45 \\
\hline $\begin{array}{c}\text { Importance to competitiveness collaboration } \\
\text { admin and operations externally }\end{array}$ & Operational & -0.04 & 0.08 & 0.11 & 0.05 & -0.03 & 0.71 & 0.37 \\
\hline $\begin{array}{c}\text { Importance to competitiveness collaboration on } \\
\text { data externally }\end{array}$ & Operational & 0.04 & 0.08 & 0.78 & 0.04 & 0.04 & 0.60 & 0.18 \\
\hline $\begin{array}{l}\text { Efficient in development new apps, projects } \\
\text { within budget and scope }\end{array}$ & Managerial & 0.45 & 0.27 & 0.10 & 0.04 & 0.55 & 0.36 & 0.41 \\
\hline
\end{tabular}




\begin{tabular}{|c|c|c|c|c|c|c|c|c|}
\hline $\begin{array}{l}\text { Efficient in tech standardization and } \\
\text { infrastructure sharing internally }\end{array}$ & Operational & 0.15 & 0.67 & 0.04 & -0.04 & 0.17 & 0.25 & 0.38 \\
\hline $\begin{array}{l}\text { Efficient in tech standardization and } \\
\text { infrastructure sharing with external partners }\end{array}$ & Operational & 0.19 & 0.77 & 0.01 & -0.04 & 0.17 & 0.12 & 0.20 \\
\hline $\begin{array}{l}\text { Efficient in administering \& operational } \\
\text { processes within firm }\end{array}$ & Operational & 0.29 & 0.76 & 0.16 & 0.14 & -0.18 & -0.14 & 0.30 \\
\hline $\begin{array}{l}\text { Efficient in administering \& operational } \\
\text { processes with external partners }\end{array}$ & Operational & 0.06 & 0.86 & 0.07 & 0.04 & 0.09 & 0.16 & 0.22 \\
\hline $\begin{array}{l}\text { Efficient at sharing standardized data } \\
\text { (product/customer/partner) internally }\end{array}$ & Operational & 0.38 & 0.56 & 0.28 & 0.12 & 0.10 & -0.14 & 0.41 \\
\hline $\begin{array}{l}\text { Efficient at sharing standardized data } \\
\text { (product/customer/partner) with external partners }\end{array}$ & Operational & 0.08 & 0.65 & 0.09 & 0.15 & 0.20 & 0.18 & 0.41 \\
\hline $\begin{array}{c}\text { Executives involved in IT investment \& } \\
\text { management decision-making }\end{array}$ & Managerial & 0.68 & 0.24 & 0.09 & 0.13 & -0.11 & -0.11 & 0.32 \\
\hline FTEs have skills to exploit new ICT trends & Managerial & 0.78 & 0.33 & 0.34 & -0.44 & 0.12 & -0.14 & 0.31 \\
\hline $\begin{array}{l}\text { FTEs have skills to innovate business models and } \\
\text { drive change }\end{array}$ & Managerial & 0.88 & 0.03 & -0.45 & -0.14 & 0.02 & -0.30 & 0.31 \\
\hline $\begin{array}{l}\text { FTE have skills in deploy innovative IT apps and } \\
\text { services }\end{array}$ & Managerial & 0.88 & 0.15 & 0.22 & -0.04 & 0.13 & -0.21 & 0.23 \\
\hline $\begin{array}{c}\text { FTE leading inter-disciplinary staff \& influence } \\
\text { stakeholders }\end{array}$ & Managerial & 0.74 & 0.17 & 0.22 & 0.03 & 0.04 & 0.17 & 0.38 \\
\hline $\begin{array}{l}\text { Managers who make growth have } \\
\text { ICT/management/Entrepreneurship training }\end{array}$ & Strategic & 0.54 & 0.28 & 0.13 & 0.02 & 0.25 & 0.06 & 0.56 \\
\hline $\begin{array}{l}\text { Firms reports insufficient skills; time and budget, } \\
\text { but continue selling products }\end{array}$ & Strategic & 0.05 & 0.07 & -0.37 & 0.79 & 0.06 & 0.15 & 0.30 \\
\hline $\begin{array}{c}\text { Firms reports insufficient skills; time and budget, } \\
\text { but launch new products }\end{array}$ & Strategic & -0.15 & 0.17 & -0.39 & 0.87 & 0.07 & -0.05 & 0.24 \\
\hline $\begin{array}{l}\text { Firms reports insufficient skills; time and budget, } \\
\text { but continue creating jobs }>100 \%\end{array}$ & Strategic & -0.07 & -0.07 & 0.43 & 0.81 & 0.12 & -0.05 & 0.29 \\
\hline
\end{tabular}

Note: Total observations for all variables: 204. Rotation criteria (oblimin) was applied with respect to the orthogonal and/or oblique class of rotations. Cronbach's $\alpha$ lpha represents the expected correlation of one test with an alternative form containing the same number of items. The square root of $\alpha$ is the estimated correlation of a test with errorless true scores.

Source: Empirica e-leadership online survey data (2014) and follow up survey 2020 


\begin{tabular}{|l|c|c|c|c|}
\hline \multicolumn{1}{|c|}{ Variables } & Mean & St. dev & Min & Max \\
\hline Dep. variable - Sales change (\%) & 23.51 & 65.02 & -75.00 & 300.00 \\
\hline $\begin{array}{l}\text { Dep. variable- Productivity ratio } \\
\text { (sales to employment change) }\end{array}$ & 0.22 & 0.85 & -1.50 & 6.40 \\
\hline factor1 - skills & 0.00 & 0.90 & -2.31 & 2.28 \\
\hline factor2- infrastructure & 0.00 & 1.05 & -2.25 & 2.09 \\
\hline factor3 -IT coordination & -0.05 & 1.05 & -3.02 & 1.49 \\
\hline factor4- Resilience & 0.07 & 1.18 & -0.85 & 6.83 \\
\hline factor5 - Mobility & 0.04 & 1.05 & -1.79 & 2.83 \\
\hline factor6 - Collaboration & 0.02 & 0.97 & -2.99 & 2.38 \\
\hline $\begin{array}{l}\text { Employment in initial year 2012 } \\
\text { (FTEs) }\end{array}$ & 34.10 & 46.27 & 5.00 & 225.00 \\
\hline Product change (months) & 28.18 & 30.24 & 0.00 & 155.31 \\
\hline
\end{tabular}

Note: Total observations for all variables: 204 with 102 firms in the survey; Factor loadings are built using rotation matrix with al factors be orthogonal to each other and normalized around zero, although they vary from negative lack of factors to positive - abunndance of factor.

Source: Empirica e-leadership online survey data (2014) and follow up survey 2020

Table 4: Regression results

\begin{tabular}{|c|c|c|c|c|c|c|}
\hline Specification & 1 & 2 & 3 & 4 & 5 & 6 \\
\hline Dependent variable & \multicolumn{3}{|c|}{ Sales growth } & \multicolumn{3}{|c|}{ Firm Productivity } \\
\hline factor 1 - skills (Managerial) & $\begin{array}{l}13.02 * * \\
(6.11) \\
\end{array}$ & $\begin{array}{l}18.18 * * \\
(9.90)\end{array}$ & $\begin{array}{l}22.12 * * \\
(10.02)\end{array}$ & $\begin{array}{l}0.21 \text { ** } \\
(0.12) \\
\end{array}$ & $\begin{array}{l}0.20 * * \\
(0.15) \\
\end{array}$ & $\begin{array}{l}0.27 * * \\
(0.17) \\
\end{array}$ \\
\hline factor2- infrastructure (Operational) & $\begin{array}{l}-4.78 \\
(3.85)\end{array}$ & $\begin{array}{l}-4.49 \\
(4.10)\end{array}$ & $\begin{array}{l}-4.65 \\
(4.90)\end{array}$ & $\begin{array}{l}0.08 \\
(0.10)\end{array}$ & $\begin{array}{l}0.05 \\
(0.12)\end{array}$ & $\begin{array}{l}0.06 \\
(0.12)\end{array}$ \\
\hline factor3 -IT coordination (Operational) & $\begin{array}{l}0.58 \\
(6.06)\end{array}$ & $\begin{array}{l}-3.12 \\
(6.50)\end{array}$ & $\begin{array}{l}-3.19 \\
(6.50)\end{array}$ & $\begin{array}{l}0.12 \\
(0.06)\end{array}$ & $\begin{array}{l}0.13 \\
(0.06)\end{array}$ & $\begin{array}{l}0.15 \\
(0.06)\end{array}$ \\
\hline factor4- Resilience (Strategic) & $\begin{array}{l}-2.22 \\
(2.23) \\
\end{array}$ & \begin{tabular}{|l|}
-4.67 \\
$(2.45)$ \\
\end{tabular} & $\begin{array}{l}-3.61 \\
(3.12) \\
\end{array}$ & $\begin{array}{l}-0.02 * \\
(0.01) \\
\end{array}$ & $\begin{array}{l}-0.08^{* *} \\
(0.03) \\
\end{array}$ & $\begin{array}{l}-0.07 * * \\
(0.02) \\
\end{array}$ \\
\hline factor5 - Mobility (Strategic) & $\begin{array}{l}-0.98 \\
(0.70)\end{array}$ & $\begin{array}{l}0.30 \\
(0.59)\end{array}$ & $\begin{array}{l}0.58 \\
(0.68)\end{array}$ & $\begin{array}{l}0.07 \\
(0.04)\end{array}$ & $\begin{array}{l}0.18 \\
(0.19)\end{array}$ & $\begin{array}{l}0.23 \\
(0.19)\end{array}$ \\
\hline factor6 - Collaboration (Operational) & $\begin{array}{l}11.00 * * \\
(6.16)\end{array}$ & $\begin{array}{l}8.89^{* *} \\
(4.14)\end{array}$ & $\begin{array}{l}9.98^{* *} \\
(4.01)\end{array}$ & $\begin{array}{l}0.09 * \\
(0.05)\end{array}$ & $\begin{array}{l}0.10 * * \\
(0.05)\end{array}$ & $\begin{array}{l}0.11 * * \\
(0.06)\end{array}$ \\
\hline Employment (2012 year) & & $\begin{array}{l}0.20 \\
(0.18)\end{array}$ & $\begin{array}{l}0.14 \\
(0.12)\end{array}$ & & $\begin{array}{l}0.19 \\
(0.17)\end{array}$ & $\begin{array}{l}0.18 \\
(0.12)\end{array}$ \\
\hline Products /services changed, $\%$ & & $\begin{array}{l}1.12 \\
(0.53)\end{array}$ & $\begin{array}{l}0.52 \\
(0.53)\end{array}$ & & $\begin{array}{l}0.02 \\
(0.02)\end{array}$ & $\begin{array}{l}0.05 \\
(0.06)\end{array}$ \\
\hline factor $4 \mathrm{x}$ factor 1 & & & $\begin{array}{l}20.55^{* *} \\
(9.11) \\
\end{array}$ & & & $\begin{array}{l}0.39 * * \\
(0.20)\end{array}$ \\
\hline factor $4 \mathrm{x}$ factor 2 & & & $\begin{array}{l}3.02 \\
(2.12)\end{array}$ & & & $\begin{array}{l}0.05 \\
(0.03) \\
\end{array}$ \\
\hline factor $4 \mathrm{x}$ factor 3 & & & $\begin{array}{l}3.04 \\
(2.54)\end{array}$ & & & $\begin{array}{l}0 . .03 \\
(0.02)\end{array}$ \\
\hline factor $4 \mathrm{x}$ factor 5 & & & $\begin{array}{l}0.09 \\
(0.12) \\
\end{array}$ & & & $\begin{array}{l}0.21 \\
(0.13)\end{array}$ \\
\hline factor $4 \mathrm{x}$ factor 6 & & & $\begin{array}{l}-7.14 * * \\
(4.11) \\
\end{array}$ & & & $\begin{array}{l}-0.07 * * \\
(0.03) \\
\end{array}$ \\
\hline The inverse Mills ratio for disclosure bias & $\begin{array}{l}-0.651 * \\
(0.37)\end{array}$ & $\begin{array}{l}-0.658^{*} \\
(0.37)\end{array}$ & $\begin{array}{l}-0.663^{*} \\
(0.37)\end{array}$ & \begin{tabular}{l}
\multicolumn{1}{c}{} \\
$0.151^{* *}$ \\
$(0.06)$
\end{tabular} & $\begin{array}{l}-0.08 * * \\
(0.01)\end{array}$ & $\begin{array}{l}-0.03^{*} \\
(0.01)\end{array}$ \\
\hline
\end{tabular}




\begin{tabular}{|c|c|c|c|c|c|c|}
\hline $\begin{array}{l}\text { The inverse Mills ratio for technology } \\
\text { active bias }\end{array}$ & $\begin{array}{l}-2.534 * \\
(1.49)\end{array}$ & $\begin{array}{l}-2.614 * \\
(1.49)\end{array}$ & $\begin{array}{l}-2.467 * \\
(1.49)\end{array}$ & $\begin{array}{l}-0.53 \\
(0.49)\end{array}$ & $\begin{array}{l}0.61^{* *} \\
(0.28)\end{array}$ & $\begin{array}{l}0.67 * * \\
(0.30)\end{array}$ \\
\hline Industry controls & No & Yes & Yes & $\mathrm{No}$ & Yes & Yes \\
\hline Country controls & No & Yes & Yes & No & Yes & Yes \\
\hline Constant & $\begin{array}{l}23.01 * * * \\
(6.14)\end{array}$ & $\begin{array}{l}21.00^{* *} \\
(4.33)\end{array}$ & $\begin{array}{l}24.91 * * * \\
(5.22)\end{array}$ & $\begin{array}{l}0.23 * * * \\
(0.06)\end{array}$ & $\begin{array}{l}0.19 * * * \\
(0.05)\end{array}$ & $\begin{array}{l}0.18^{* * *} \\
(0.02)\end{array}$ \\
\hline Observations & 204 & 204 & 204 & 204 & 204 & 204 \\
\hline R-squared & 0.17 & 0.44 & 0.44 & 0.21 & 0.31 & 0.32 \\
\hline
\end{tabular}

Note: Level of statistical significance is * $0.1 \%$; ** $0.05 \%$; and $* * * 0.01 \%$. Standard errors clustered by country Number of firms 102.

Source: Authors' calculation

\section{Appendix A}

Table A1: Selection models.

\begin{tabular}{|c|c|c|c|c|c|c|}
\hline \multirow{2}{*}{ Two-step Heckman approach } & \multicolumn{3}{|c|}{ Model 1: Disclosure $=1$} & \multicolumn{3}{|c|}{ Model 2: Technology Active $=1$} \\
\hline & $\mathrm{dx} / \mathrm{dy}$ & SE & $\begin{array}{c}\text { Marginal } \\
\text { effects }\end{array}$ & $\mathrm{dx} / \mathrm{dy}$ & SE & $\begin{array}{c}\text { Marginal } \\
\text { effects }\end{array}$ \\
\hline Age $(\log )$ & 1.01 & $0.38 * * *$ & 3.71 & 0.26 & 0.29 & 3.71 \\
\hline \% IT Budget spent on developing new apps & 0.24 & 0.25 & 0.14 & & & \\
\hline$\%$ of total IT budget spent on cloud-based services & -0.34 & $0.21 *$ & 0.35 & & & \\
\hline$\%$ of total IT budget spent on Mobile devices & -0.16 & 0.30 & 0.18 & & & \\
\hline$\%$ IT Budget spent on Big data and business analytics & -0.03 & 0.22 & 0.19 & & & \\
\hline$\%$ of total IT budget spent on Internet of things & 0.28 & 0.19 & 0.33 & & & \\
\hline$\%$ of total IT budget spent on Social Media & -0.49 & 0.41 & 0.08 & & & \\
\hline $\begin{array}{l}\text { Importance to competitiveness collaboration on IT apps \& } \\
\text { infrastructure in-house }\end{array}$ & & & & 0.35 & $0.28 *$ & 0.51 \\
\hline $\begin{array}{l}\text { Importance to competitiveness collaboration on admin \& } \\
\text { operations processes in-house }\end{array}$ & & & & 0.25 & 0.34 & 0.19 \\
\hline $\begin{array}{l}\text { Importance to competitiveness collaboration on data in- } \\
\text { house }\end{array}$ & & & & -0.17 & 0.21 & 0.18 \\
\hline $\begin{array}{l}\text { Importance to competitiveness collaboration IT apps and } \\
\text { infrastructure externally }\end{array}$ & & & & 0.89 & $0.34 * *$ & 0.13 \\
\hline $\begin{array}{l}\text { Importance to competitiveness collaboration admin and } \\
\text { operations externally }\end{array}$ & & & & 0.30 & $0.20 * *$ & 0.34 \\
\hline $\begin{array}{l}\text { Importance to competitiveness collaboration on data } \\
\text { externally }\end{array}$ & & & & 0.27 & 0.34 & 0.08 \\
\hline Employment in initial year 2012 (FTEs) & & & & -0.35 & $0.19 *$ & 0.30 \\
\hline $\begin{array}{l}\text { Country dummies (reference country=UK) } \\
\text { Industry } \\
\text { Year dummies (reference year=2015) }\end{array}$ & & $\begin{array}{l}\text { Yes } \\
\text { Yes } \\
\text { Yes }\end{array}$ & & & $\begin{array}{l}\text { Yes } \\
\text { Yes } \\
\text { Yes }\end{array}$ & \\
\hline $\begin{array}{c}\text { Number of obs. } \\
\text { Likelihood ratio test Wald chi2 } \\
\text { Prob }>\text { Chi2 } \\
\text { Pseudo-R2 }\end{array}$ & & $\begin{array}{c}2603 \\
47.5 \\
0.00 \\
0.325\end{array}$ & & & $\begin{array}{c}271 \\
36.28 \\
0.00 \\
0.160\end{array}$ & \\
\hline
\end{tabular}

Note: Marginal effects and robust standard errors from probit regression model are shown. ***, ** and *

Significance at the $1 \%, 5 \%$ and $10 \%$ levels, respectively. Both models include year controls, which are jointly significant. Model 1 and Model 2 the inverse Mills ratios calculated are used on the final stage to predict sales and productivity.

Source: Empirica e-leadership online survey data (2014) and follow up survey 2020 